\title{
Para centralizar o periférico: personagem, raça e classe em Aquarius
}

\section{Centralizing peripheral: character, race and class in Aquarius}

\section{Centralizar lo periférico: personaje, raza y clase en Aquarius}

\author{
Luís Henrique Marques RIBEIRO ${ }^{1}$ \\ Luiz Antonio Mousinho MAGALHÃES ${ }^{2}$
}

\section{Resumo}

O filme Aquarius, de Kleber Mendonça Filho, não tematiza explicitamente a questão racial. Contudo, a forma secundária, descolada do eixo principal da narrativa, parece obter um efeito centralizante para o entendimento de camadas de sentido enquanto obra que pensa a realidade brasileira. As relações que a personagem principal, de sugestivo nome Clara, estabelece com as personagens empregadas domésticas no filme, parece indicar a construção daquilo que pretendemos chamar de representações raciais complexas no cinema brasileiro.

Palavras-chave: Aquarius. Kleber Mendonça Filho. Racismo.

\begin{abstract}
The film Aquarius, by Kleber Mendonça Filho, does not explicitly about the racial issue. However, the secondary form, detached from the main axis of the narrative, seems to have a centralizing effect for the understanding of layers of meaning as a work that thinks the Brazilian reality. The relations that the main character, with the suggestive name Clara, establishes with the characters employed in the house in the film seems to indicate the construction of what we intend to call complex racial representations in Brazilian cinema.
\end{abstract}

Keywords: Aquarius. Kleber Mendonça Filho. Racism.

\footnotetext{
1 Doutorando pelo Programa de Pós-Graduação em Cinema e Audiovisual da Universidade Federal Fluminense. Mestre em Letras pelo Programa de Pós-Graduação em Letras da Universidade Federal da Paraíba. Desenvolve pesquisa sobre representações raciais no cinema brasileiro contemporâneo. E-mail: dizerluis@gmail.com. ORCID: 0000-0002-7227-2027.

2 Professor Titular do Departamento de Comunicação, da Pós-graduação em Letras e da Pós-graduação em Comunicação da Universidade Federal da Paraíba - UFPB. Desenvolve pesquisa junto ao CNPq (PQ) sobre as relações entre ficção e sociedade. É autor de Uma escuridão em movimento - relações familiares em Clarice Lispector (1997) e de A sombra que me move - ensaios sobre ficção e produção de sentido (cinema, literatura, TV) (2012), publicados pela EDUFPB. E-mail: luizantoniomousinho@gmail.com. ORCID: 0000-0002-7730-3195.
} 


\section{Resumen}

La película Aquarius, de Kleber Mendonça Filho, no aborda explícitamente la cuestión racial. Sin embargo, la forma secundaria, desprendida del eje principal de la narrativa, parece tener un efecto centralizador para la comprensión de las capas de sentido como una obra que piensa la realidad brasileña. Las relaciones que el protagonista, del sugerente nombre Clara, establece con los personajes domesticados de la película parecen indicar la construcción de lo que pretendemos llamar representaciones raciales complejas en el cine brasileño.

Palabras clave: Aquarius; Kleber Mendonça Filho; Racismo.

\section{Introdução}

Embora não haja uma associação direta com a temática racial, Aquarius (2016), do diretor pernambucano Kleber Mendonça Filho, percorre sutilmente aspectos fundacionais da sociedade contemporânea brasileira no que diz respeito às relações de classe e raça. O modo secundário, descolado da base central da narrativa, parece obter um efeito centralizante para a possibilidade de analisar a obra enquanto objeto artístico que interpreta a realidade brasileira.

Destacamos o enfoque metodológico em observar as representações sociais no filme como relacionadas ao campo da Comunicação, na medida em que nos leva à investigação de aspectos "da dimensão humana (...) mediatizados por dispositivos técnicos", para falar com Luiz Martino (MARTINO, 2001, p.31). Trata-se, conforme o autor, de propor "uma leitura do social realizada a partir dos meios de comunicação". No nosso caso, o cinema.

Podemos dizer também que nossa proposta está inserida nos estudos de mídia, na medida em que encaramos o cinema, de acordo com Cristiane Freitas Gutfreind, como "uma mídia que constrói imaginários narrativos, sonoros e visuais que configuram o conhecimento, a estética, a linguagem e a produção simbólica dos afetos" (GUTFREIND, 2014 , p. 266). Como destaca a autora, "eleito como objeto de estudo" o cinema "tornouse um instrumento documental que tem papel fundamental na construção do saber técnico, na formação de referências teóricas diversas e nas estratégias socioculturais" (GUTFREIND, 2014, p. 266). Gutfreind ressalta ainda que a natureza artística do cinema 
"e ao mesmo tempo industrial pode tensionar os sistemas de representação estabelecidos e possibilitar um questionamento do homem sobre o mundo e sobre ele mesmo".

Nosso intuito metodológico se dá na observância da articulação da linguagem como "repositório objetivo de vastas acumulações de significados e experiências" (BERGER; LUCKMANN, 2001, p.57) e de tomar a mídia cinema como um "meio de pensar sobre a vida social que privilegia a ação, o significado e o poder do simbólico" (SILVERSTONE, 2002, p.134). Por conseguinte, pensamos o discurso cinematográfico como uma construção que envolve sujeito, história e linguagem, que produz sentido "por meio de um insistente retorno de figuras, de sínteses-narrativas, de representações que constituem o imaginário social", (GREGOLIN, 2003, p.96). O conceito de destaque na análise do artigo será a categoria personagem, no entendimento de que "é a personagem que com mais nitidez torna patente a ficção, e através dela a camada imaginária se adensa e se cristaliza" (CANDIDO, 1992, p.14).

\section{Racismo, classe e personagem}

Este artigo é um exercício de atenção sobre o racismo brasileiro, cuja sutileza e o silêncio deixam mais difícil de perceber suas expressões (MUNANGA, 2017). De modo metafórico, é preciso educar nossos ouvidos para todos os sons negros que estão enraizados identitariamente no Brasil e, consequentemente, aparecem na díade ausência/presença, nas produções audiovisuais do país.

O enredo do filme, fundamentalmente, entre outros aspectos, se desenvolve em torno de Clara, do prédio Aquarius, e de Diego. Clara é uma jornalista aposentada que resiste às tentativas invasivas da construtora Bonfim, na figura de Diego, neto do dono da empresa, de compra do seu apartamento. A ação se desenvolve em torno dessa tríade. Porém, outras camadas são criadas durante o prosseguimento narrativo, que complexificam a ação principal: o racismo é uma delas.

Dessa maneira, Kleber Mendonça Filho aborda a questão racial como componente de uma realidade mais ampla, que seria a realidade brasileira. Ele traz o dado social do negro e do racismo na sociedade brasileira organizado enquanto o "outro", o “estranho", o "não familiar" (FANON, 2008; FREUD, 1976). Estruturalmente, a narrativa organiza-se colocando o negro como esse ser externo, cujas subjetividades não 


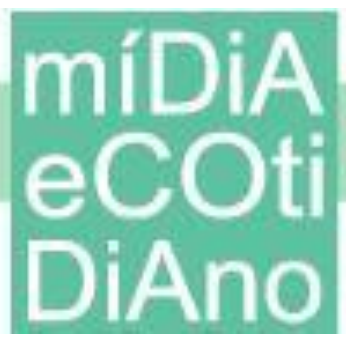

acessamos. O texto fílmico dos longas do diretor pernambucano traz muitos desses temas, de modo sutil, mas presente.

Isso posto, há uma fusão de dois planos: o filme aborda a questão racial de maneira similar ao seu enquadramento na cultura brasileira, secundariamente. Observar justamente quando a obra traz a questão racial de maneira secundária, tanto em sua temática como em sua estrutura, parece ser um caminho analítico proveitoso para as possibilidades de enquadramento das representações raciais no cinema brasileiro contemporâneo. Ou seja, examinar se a periferia pode adquirir uma importância centralizante para o entendimento analítico do filme alinha-se com aquilo que chamamos de representações raciais complexas no cinema brasileiro contemporâneo.

Em Aquarius, parece haver uma quebra e/ou tensionamento de estereotipias sobre as subjetividades negras. Isso é costurado ao longo do filme nos momentos em que, no bairro de classe média alta, Boa Viagem, no Recife (PE), o traficante branco de olhos azuis é morador e vende drogas por detrás dos quiosques da orla da praia ou quando garotos negros periféricos sorriem e se divertem na praça do bairro, ao invés de assaltar. Ou ainda, no observar um negro que se formou no curso de direito na universidade pública, em 1969, época em que o ambiente de ensino superior era quase integralmente formado por pessoas brancas. $\mathrm{Na}$ historiografia dos personagens negros no cinema (STAM, 2008) e também na telenovela (ARAÚJO, 2000), o movimento destoa do abordado em Aquarius.

Se por um lado há uma quebra de estereótipos, o filme também reproduz problemáticas raciais da realidade brasileira que não necessariamente apontam para um caminho de desvio desses estereótipos. Ele dá a ver essas relações, como um recurso de construção de elementos da sociedade que se imbricam na estrutura da obra (CANDIDO, 2006). É o caso da relação de Clara com as empregadas domésticas Ladjane e Juvenita. É pertinente destacar o pensamento de Bragança, Siciliano e Pinto (2019) ao apontar a questão do emprego doméstico, no cinema e na televisão brasileiras, como um "espaço de permanência de práticas coloniais" (p.113). As empregadas "são invisíveis aos olhares desatentos, configurando-se como elementos de uma paisagem cotidiana” (p.111).

“Ladjane! O que é que tem pro almoço?”. Essa é a primeira fala de Clara, a jovem senhora de 65 anos. Clara está na sala e estica o seu corpo, para, em seguida, ir à 
praia, enquanto Ladjane, a empregada, está na cozinha, no preparo do almoço. A resposta da pergunta de Clara é interrompida pela porta da cozinha, que bate abruptamente frente à ventania marítima. $\mathrm{O}$ corte seco do movimento da porta faz referência a uma atmosfera de suspense/terror característica do estilo de Kleber Mendonça Filho, algo já pontuado em Caetano e Gomes (2020). Essa quebra repentina acresce ao diálogo uma camada de atenção entre a fala de Clara e a fala de Ladjane. O barulho coloca uma voltagem num diálogo cotidianamente repetido. Além de estabelecer o gesto inaugural da natureza da relação entre as duas personagens, que veremos ao longo do filme: uma relação de convívio diário há anos, porém com demarcações não ditas. Também inscreve as delimitações espaciais dos sujeitos: a porta bate também para lembrar as fronteiras de pertença de Ladjane, ou seja, na cozinha, uma vez que chama a atenção para a própria divisão arquitetônica do apartamento multifamiliar da década de 1960, construído numa adaptação da Casa Grande, com os espaços organizados para que as empregadas não se misturem com os outros cômodos da casa. A câmera observa Ladjane abrir a porta, numa perspectiva externa, o que reforça o sentido de que aquele local é o espaço de Ladjane. E, de fato, é o espaço em que a empregada doméstica mais aparece no filme.

Em outra cena, Clara fala que quer mostrar algo para Ladjane. Na varanda, depois de um beijo na bochecha da empregada, Clara dá a sua caneca para ela segurar e vai para a sala, onde toca no piano, desajeitadamente, Canções de cordialidade (Manuel Bandeira e Villa-Lobos), como forma de desejar feliz aniversário para Ladjane. A música, ao que parece, era uma tradição de família, uma vez que também foi tocada no aniversário de Tia Lúcia.

"Ela lembrou", Ladjane fala logo depois do parabéns dado por Clara. Ao que esta fala: "tu sabe que pode contar comigo pra tudo, num sabe?". É nesse sentido que "se o racismo no estilo americano pode ser um tapa na cara, o racismo no estilo brasileiro pode ser como um abraço que sufoca: no Brasil, o racismo é abafado, camuflado, disfarçado, difícil de se detectar" (STAM, 2008, p. 83). A dificuldade de identificar o racismo não se dá no fato de não haver casos muito bem delineados que, inclusive, ganham agendamento dos jornais de grande circulação. Mas, sim, o obstáculo está numa isonomia dos sujeitos perante o fato. O outro é que seria o único que pode e deve ser 


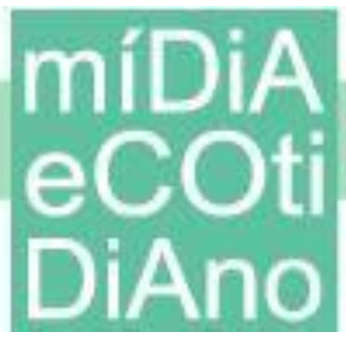

racista, nunca nós, nem nossas ações cotidianas. A lógica do enunciado seria essa: vejam o quanto ele é racista para que o "meu pequeno racismo" não receba atenção.

Não sabemos muito sobre a história de Ladjane, a não ser que ela mora próximo a Clara, em Brasília Teimosa, e que seu filho, cujo nome desconhecemos, foi assassinado, de maneira impune, num acidente de trânsito. Embora o filho de Ladjane não seja negro, ao pensar socialmente nos casos de impunidade no Brasil, percebemos que quem é negro e pobre desponta nessas situações como vítima. Um dado que é imagem de uma realidade, assim como é o fato de, no churrasco do aniversário de Ladjane, tomarmos conhecimento que a sua irmã, Lala, trabalha para Letícia, amiga de Clara, que também está na festa.

Se antes, no cinema brasileiro, não havia esse movimento simpático de atravessamento de fronteiras da patroa com a empregada, agora, a patroa vai à favela junto com seu sobrinho e a namorada do sobrinho, no caso Tomás e Júlia. Todas essas relações são ecos de um Brasil escravocrata, cuja abolição não trouxe políticas de inserção social do negro, mas, sim, apontou para uma continuidade de exploração, cujos contornos ficaram mais tênues, difíceis de localizar, porém se fazem presentes. A desigualdade racial aparece dentro desses vínculos de assimetrias dissimuladas. Nesse sentido,

A existência, a intensidade e a intimidade do convívio dos 'brancos' com os 'negros' não são, por si mesmas, evidências indiscutíveis de 'igualdade racial'. Todas essas coisas se desenrolaram através da mais completa, rígida e insuperável desigualdade racial (FERNANDES, 2008, p. 380, grifo do autor).

Ao notarmos que, em nenhum momento, Ladjane emite algum posicionamento ou comentário sobre a venda do apartamento, percebemos que há um isolamento dessa questão voltada apenas para o âmbito familiar e círculos de amizade. Apesar de que Ladjane sempre está ao lado de Clara nos momentos de confronto com Diego, o que nos permite observar a defesa explícita que ela nutre pela patroa.

Contudo, a falta de comunicação entre empregados e patrões acarretada pelo abismo social entre os mundos de ambos é ressaltada no filme. Isso é colocado à medida que as imagens avançam, mostrando a instância narrativa que observa e comenta o fosso entre as classes. Haveria uma artificialidade de discursos, caso existisse um diálogo direto, sobre a venda do apartamento, entre a empregada e a patroa. Caso Ladjane 
defendesse a permanência de Clara, como se é subentendido, ficaria explícita a dissonância entre os lugares sociais ocupados por ambas, se adicionaria à narrativa um componente panfletário que, talvez, simplificasse as questões ao espectador.

Em outras palavras, caso Ladjane comentasse sobre o absurdo que seria tirar Clara à força de sua casa (numa aplicação de pesos iguais das suas próprias problemáticas de espaço urbano advindas de Brasília Teimosa), veríamos uma ingenuidade da empregada e do filme, que tornaria mais nítida a questão do privilégio em Clara. A dinâmica em Aquarius caminha na direção das sutilezas, dos dados diegéticos que quase podem passar despercebidos, caso o espectador não esteja atento às imagens em movimento. É mostrar o sentimento de ter que sair do seu lar, que pode ser acessado a todo ser humano, mas também observar as complexidades que envolvem cada tipo de lar que vai estar localizado em determinado espaço social e econômico.

À vista disso, o único momento em que se fala explicitamente sobre raça é quando Clara exige explicações de Diego sobre a festa que aconteceu no apartamento acima do seu. Através da fala de Diego, ao utilizar os termos "família de pele mais morena", que a questão racial é tocada para expor ironicamente o lugar social ocupado por Clara. Destaca-se que a questão racial, neste diálogo entre Clara e Diego, apareceria como consequência dos tensionamentos de classe levantados nas confrontações que o empresário neoliberal Diego erige em torno de Clara, que na cena é posta enquanto uma intelectual tradutora de demandas sociais (RIDENTI, 2000).

A ideia do intelectual de classe média que, consideravelmente nos anos 1960, teve efeito de porta-voz do povo brasileiro, colocada na esteira dos discursos políticos, parece encontrar sedimentação na constituição da personagem Clara, cujo papel, nesta cena, bosqueja no desejo de talvez atualizar a discussão dessa figura do imaginário político da cultura brasileira. O Cinema Novo, por exemplo, tomou-se enquanto mensageiro-intérprete dos problemas sociais e econômicos do país. Isso estava articulado ao fato de que,

Numa sociedade na qual os direitos de cidadania não se generalizam para o conjunto da população, em que as classes não se reconhecem enquanto tais, não identificando claramente o seu outro, encontrando dificuldades para fazer-se ouvir, ou mesmo para articular a própria voz, 
despontam setores ventríloquos nas classes médias, dentre os quais alguns intelectuais, inclusive os artistas, que têm canais diretos para se expressar, na televisão, no rádio, no cinema, no teatro, nos livros, nas artes plásticas, nos jornais etc. (RIDENTI, 2000, p. 55, grifo do autor).

O desenrolar da cena entre a jornalista aposentada e o neto do dono da construtora Bonfim acontece da seguinte forma: Clara critica o lugar de elite ocupado por Diego, utiliza como argumento o dinheiro como elemento estruturante de uma irônica firmeza moral, que, dessa maneira, seria esvaziado de uma educação, cuja existência, na verdade, apareceria na natureza da "gente pobre" - e, aqui, há uma sugestão, na fala de Clara, de idealização da pobreza (a pureza moral que estaria inerente às pessoas de classe baixa). Diego dá continuidade ao argumento financeiro para falar, de maneira sarcástica, das origens familiares de Clara. O uso irônico da meritocracia para explicitar o lugar, também de elite, ocupado por Clara, aparece na demarcação da situação social e econômica de famílias de pele mais morena. A metáfora da família destaca e racializa a noção de grupo. Assim, Diego explicita o fato de Clara não vir de uma família de pele morena e, portanto, não ter "batalhado e dado muito suor para ter o que tem"; além de colocá-la em situação de equivalência com ele, na sugestão de também igualdade do caráter inerente à elite. É por conta da sua favorável situação de classe, econômica e social, que Clara tem o privilégio de reivindicar a permanência no seu lar.

O filme parece destacar a falta da noção do lugar de classe média alta que Clara ocupa. O que é confirmado, em seu discurso, ao estabelecer uma distância com Diego, ao falar da "gente de elite" como pessoas que se acham privilegiadas. O jogo de bom e mau raciocinado por Clara é tensionado na rememoração da mestiçagem como estruturante da constituição de grupos em abismos sociais.

Um dado que é construído do início ao final do filme é o fato de Clara pertencer a uma elite, no sentido de acesso a códigos culturais, sociais e econômicos afastados das camadas pobres. Embora haja uma recusa, pela personagem, de associação ao grupo 
social, Clara situa-se no espaço social da elite no Brasil: de pele branca ${ }^{3}$ e traços finos. Embora não seja o estereótipo caucasiano de loira dos olhos azuis. Porém, a identidade de elite é reforçada no próprio nome da personagem, que faz um contraponto com o adjetivo escura, historicamente utilizado em formações discursivas racistas e que organizam socioeconomicamente a representação do lugar do negro no Brasil. Clara é de elite, pois tem um capital simbólico que pode ser demonstrado tanto nas relações com o amigo jornalista que propicia o acesso a informações privilegiadas sobre o dono da construtora Bonfim, como em suas falas com a filha Ana Paula, quando diz que tem dinheiro suficiente pra ajudar qualquer um dos filhos, ou, no início do filme, quando vemos que morava, na década de 1980, auge da expansão urbana na zona da orla no Recife, em um apartamento multifamiliar.

Entretanto, tome-se por outra angulação, e coloquemos outro sentido para a fala de Diego, apenas como maneira de aprofundamento da análise. Se tomássemos que a sua fala não foi irônica, e ele quisesse realmente dizer que Clara veio de uma família de pele mais morena, como forma de diminuí-la, seria, no mínimo, problemático. Clara pode não ser milionária, mas ela compartilha de ferramentas interpretativas do mundo que são comuns a uma fatia da classe média e a elite. Por que Diego acentuaria um argumento que daria embasamento à própria crítica de Clara direcionada a ele? A crítica de que ele "pertence à elite, ou gente que se diz de elite". Ou seja, se Diego diz que Clara não pertence à elite, então ele concorda com Clara sobre a percepção negativa da classe social a que ele pertence, o que soaria contraditório na construção plana da subjetividade dele enquanto personagem tipo (REIS; LOPES, 1988).

Dessa maneira, preferimos admitir a cena pelo viés de tom irônico, que está explícito na voz de Diego, pois entra em sintonia com outros momentos em que o filme

\footnotetext{
3 É válido informar que a atriz que interpreta Clara, Sônia Braga, estrelou Gabriela, cravo e canela, em 1975, a telenovela baseada no romance homônimo de Jorge Amado. Em 1983, ela também protagonizou uma nova versão da obra, desta vez em formato de filme, dirigido por Bruno Barreto. No livro, a personagem é uma negra embranquecida, denotação que remete à categoria de mulata, identidade-síntese para a análise do mito da democracia racial brasileira. A caracterização da personagem nas obras audiovisuais destaca e forja intencionalmente os traços estéticos aceitáveis do corpo negro: a pele bronzeada, o cabelo ondulado, mas não crespo, a sexualidade aliada a uma ingenuidade infantil. Em nova versão da história, protagonizada por Juliana Paes, em 2012, a questão da caracterização estética gerou um debate público, pois era notável a mudança de tom da pele da atriz para a interpretação do papel.
} 


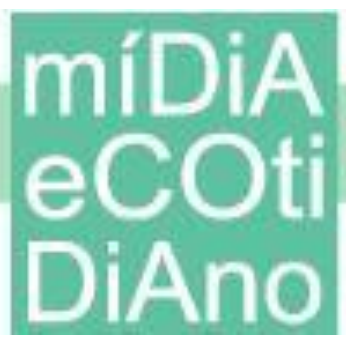

expõe as contradições de Clara. Assim, Diego diz que, na verdade, ela veio de uma família que já tinha dinheiro, igual a ele, e, por isso, ela precisaria repensar antes de criticar os modos e usos dos poderes econômicos, pois ela também os faria, como efetivamente o faz no filme, em alguns momentos. É como se ele chamasse a atenção para a estratificação entre os grupos sociais no Brasil, esvaziando as responsabilidades individuais que os integrantes advindos da elite poderiam ter, uma vez que a culpa não seria deles, mas, sim, do fato de as relações de poder nos estratos sociais serem como são desde sempre, pois se estruturam dessa forma e não vão mudar. Esse tipo de visão dialoga com a visão racista que justifica o preconceito e a inércia em sua reversão: se o mundo é racista, então a culpa de eu ser racista é do mundo e não minha, pois eu apenas replico a estrutura.

Dialogamos com a formulação de Lapera (2012, p. 129), ao apontar que "no campo do cinema brasileiro, o negro é e ao mesmo tempo não é povo no Brasil”. O uso de um personagem negro nesse tipo de enquadramento acessório, como maneira de reforçar a tensão acionada no conflito dramático pela venda e saída de Clara do apartamento através da invasão daquele espaço, acaba por recolocar a representação racial em conformidade com o esvaziamento histórico de suas possibilidades no cinema brasileiro.

\section{O álbum de família e as ausências presentes nas fotografias filmadas}

Outro momento importante no aparecimento das representações raciais complexas em Aquarius é uma das cenas de reunião da família, onde fotos do álbum de família são revistas para o casamento do sobrinho de Clara. Nela, parte da família está reunida. Ladjane está na cozinha fazendo o almoço. Em determinado momento, a empregada aparece na sala para servir vinho e mostrar a foto do filho assassinado. Depois que o faz, um silêncio constrangedor é instaurado na sala.

Dentre as muitas fotos dos álbuns, há uma sequência que chama a atenção de Clara: a empregada é negra, aparece em segundo plano, ao lado da família, o marido e a filha brancos, com o rosto/tronco cortado ou não nítido, através do enquadramento de quem tirou as fotos. No diálogo, há um momento em que Clara diz: "acabou que era uma filha da puta, roubou nossas joias, roubou joias da mamãe, lembra? da vó...essa aqui escafedeu-se lá pro Ceará. Nunca mais ninguém viu”. As fotos são um exemplo das 
relações patrão-empregada que trazem, em sua gênese, a sutileza de uma violência que tem cor e história negras, mas que é silenciada e atualizada de maneiras sutis. Sob essa lógica, Kleber comenta em entrevista:

Os ecos da escravidão estão totalmente presentes. Quando eu era criança, minha mãe chegou do cabeleireiro e disse que tinha duas mulheres conversando. Uma estava sem empregada. E perguntou à amiga se tinha alguma recomendação. E a outra disse: "Eu tenho uma: ela é preta, mas é limpinha, e pode ser uma boa solução para você”. Em 1982, duas mulheres ainda falarem isso, 90 anos depois do fim da escravidão, de certa forma era compreensível, mas inaceitável em termos históricos. Então, tudo isso, para mim, é fascinante, porque vivemos em uma sociedade ainda muito presa a muita coisa velha, embora a gente esteja na modernidade, em um mundo mais supostamente evoluído. Mas isso vai passando de geração em geração. E aí você coloca no filme, e as pessoas captam, porque é óbvio. Está na vida de todo mundo (MENDONÇA FILHO, 2016, n.p.).

A sequência de fotos do álbum de família mostra cenas cotidianas. O álbum de família é um nó que desvela o Brasil em sua síntese: as relações cordiais e sutis da intersecção da classe e raça. Juvenita é apresentada ao espectador primeiramente por conta das fotos no álbum de Clara. Na história do Brasil, as empregadas preparavam a comida, cuidavam dos filhos, muitas eram abusadas sexualmente, até como rito de iniciação à vida sexual dos adolescentes, algo cansativamente construído na produção de estereótipos em produções audiovisuais brasileiras (novelas e filmes). O corpo negro de Juvenita foi arena de confrontos e imprimiu determinados sentidos materializados em falas e percepções habituais. A figura da mulata e da doméstica é um ponto de convergência dessas experiências. Enquanto a primeira é vista em toda uma manifestação tida como natural de uma sexualidade animalesca, a segunda é vista em ponto de regime de trabalho, mas ainda influenciada pelos sentidos da primeira, a depender da situação. Em texto da antropóloga e feminista negra Lélia Gonzalez (1983), há uma análise desses estereótipos.

Quanto à doméstica, ela nada mais é do que a mucama permitida, a da prestação de bens e serviços, ou seja, o burro de carga que carrega a família e a dos outros nas costas. Daí, ela ser o lado oposto da exaltação; porque está no cotidiano. E é nesse cotidiano que podemos constatar que somos vistas como domésticas. Melhor exemplo disso são os casos 
de discriminação de mulheres negras da classe média, cada vez mais crescentes. Não adianta serem "educadas" ou estarem "bem vestidas" (afinal, "boa aparência", como vemos nos anúncios de emprego é uma categoria "branca", unicamente atribuível a "brancas" ou "clarinhas"). Os porteiros dos edifícios obrigam-nas a entrar pela porta de serviço, obedecendo instruções dos síndicos brancos (os mesmos que as "comem com os olhos" no carnaval ou nos oba-oba da vida). Afinal, se é preta só pode ser doméstica, logo, entrada de serviço. E, pensando bem, entrada de serviço é algo meio maroto, ambíguo, pois sem querer remete a gente pra outras entradas (não é "seu" síndico?). É por aí que a gente saca que não dá pra fingir que a outra função da mucama tenha sido esquecida. Está aí (GONZALEZ, 1983, p. 230-231).

As empregadas domésticas são personagens presentes na filmografia de Kleber Mendonça Filho, como em Recife frio (2009) e O Som ao Redor (2012).

Figura 1 - A falta de iluminação, na fotografia filmada e na cena do sonho de Clara, adequada para enxergar o rosto de Juvenita - referência ao efeito Shirley

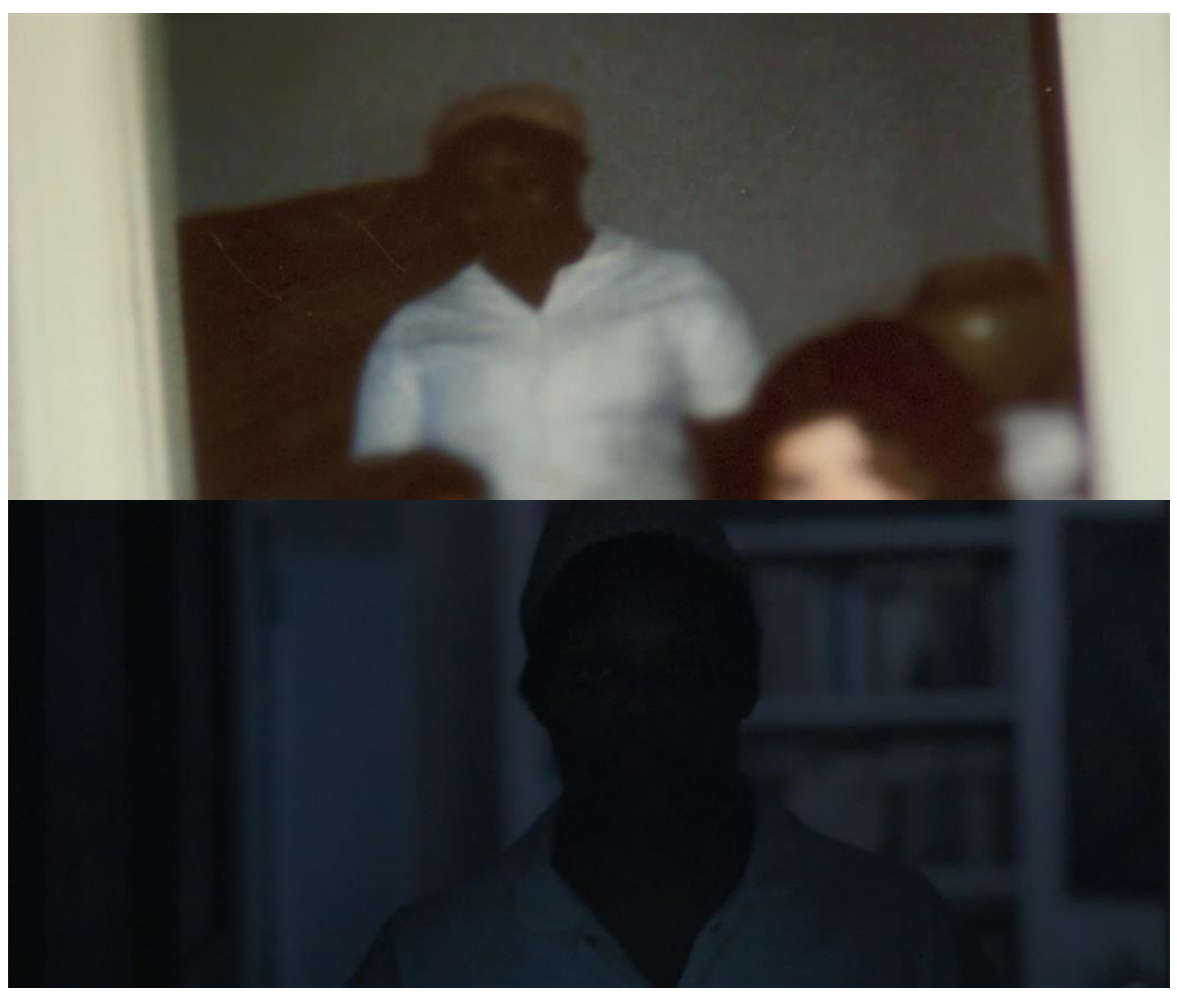

Fonte: Aquarius (MENDONÇA FILHO, 2016).

Em Aquarius, para além das representações negras na narrativa advindas do regime de imagens já sedimentado em torno da empregada doméstica na cultura brasileira, há também o comentário sobre como a técnica é resultado de concepções 
racistas. As películas "acabam por discriminar pessoas de cor escura: elas são sensíveis a certos tipos de tom de pele e exigem iluminação especial para outros" (SHOHAT; STAM, 2006, p. 273). As fotos das figuras 2, 3, 4 e 5 foram produzidas para o filme. Isso é percebido por causa do aparecimento de Adalberto, marido de Clara, e de Juvenita nas fotografias.

Na figura 1, não conseguimos ver o rosto de Juvenita, é apenas um borrão preto em contraste com o uniforme branco. Esse efeito acontece em função dos filmes de câmera não serem pensados para fotografarem os matizes negros. Os cartões Shirley, da Kodak, eram cartões que guiavam a padronização de cores e tons de pele de impressões fotográficas. Dessa forma era que

No escuro dos laboratórios fotográficos, entre 1940 e o momento presente, versões dessas imagens femininas icônicas apareceram pelo mundo todo, de forma analógica ou digital. Congeladas no tempo e na pose, sua pele clara continua a difundir um padrão normativo subliminar entre técnicos de laboratório e o público em geral. As Shirleys atravessaram décadas e continentes, definindo e balizando de maneira estreita as tonalidades de cor de pele nas imagens fotográficas, e transmitindo uma mensagem social e psicológica sutil sobre a dominância da pele branca e a posição das mulheres na indústria. Representam, ademais, uma beleza e uma estética de gênero euroocidental que correspondia, na época em que foram criadas, à noção popular masculina da aparência feminina ideal (ROTH, 2016, n.p.).

Esse padrão percorria o amplo regime de imagens: dos programas de televisão ao cinema e às fotos profissionais e de uso pessoal. É estarrecedor e sintomático saber que apenas

entre 1996 e 1997, a Kodak produziu dois cartões de referência com mulheres negras, brancas e orientais (embora todas tivessem tez bastante pálida), mas levou algum tempo até que eles começassem a circular, provavelmente porque os laboratórios estavam acostumados com suas Shirleys favoritas (ROTH, 2016, n.p.).

É dessa maneira que percebemos como a disposição da terceira e quinta fotos denunciam a inadequação da técnica para mostrar os corpos negros. Um tipo de violência 


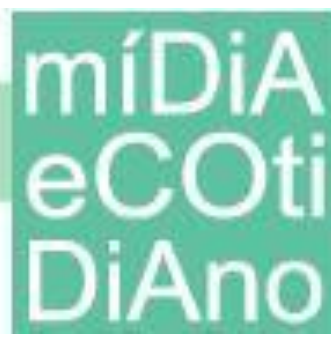

\section{PPGMC}

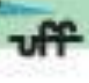

silenciosa, cujos meios técnicos construíam a ausência necessária para a manutenção da falta de representatividade negra na mídia.

Figura 2 - Juvenita, a empregada antiga que ninguém lembra o nome, com o rosto parcialmente à mostra na foto do álbum de família

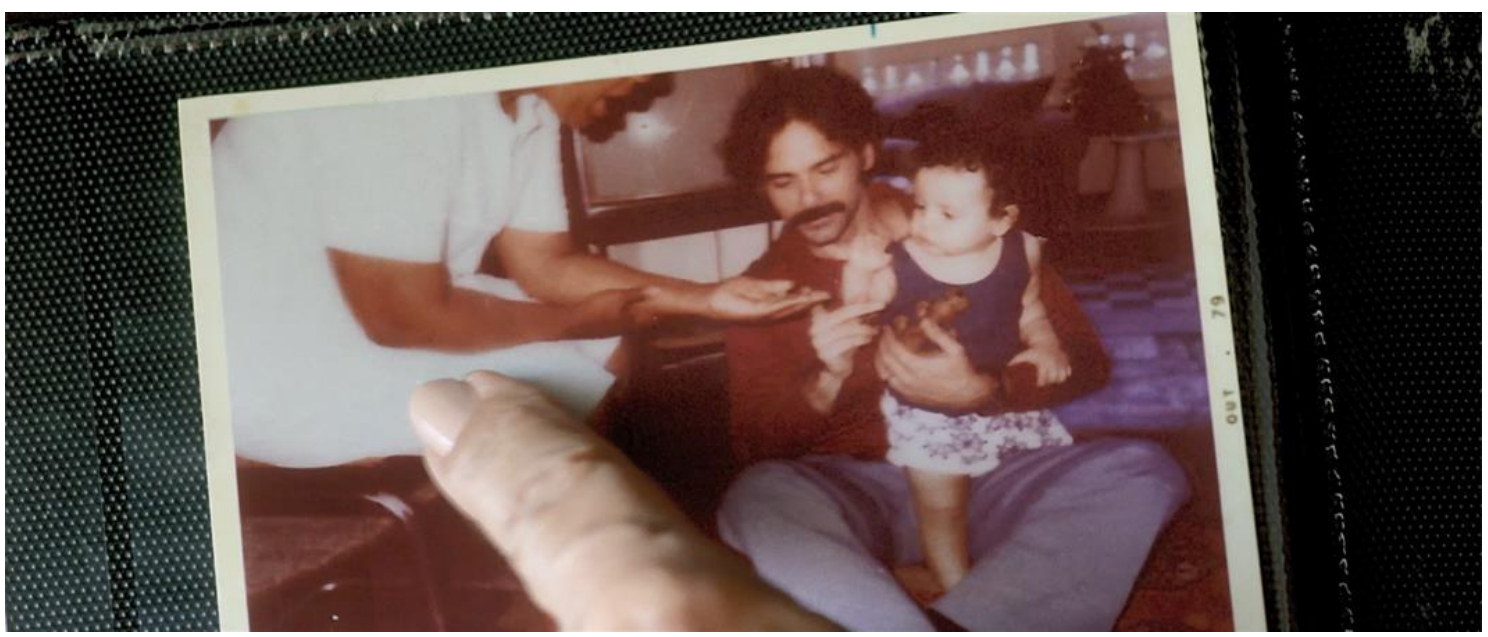

Fonte: Aquarius (MENDONÇA FILHO, 2016).

Figura 3 - Adalberto e Ana Paula, em primeiro plano, enquanto Juvenita aparece como um espírito, por conta do efeito Shirley

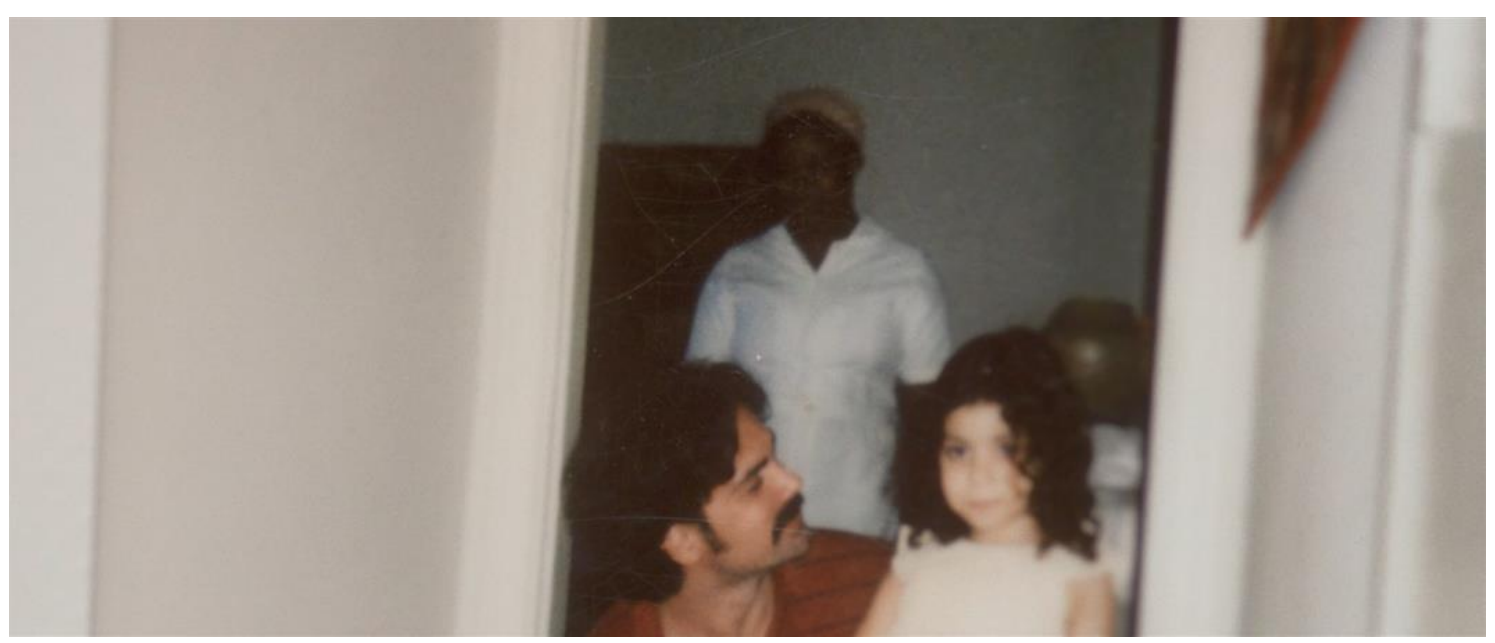

Fonte: Aquarius (MENDONÇA FILHO, 2016). 


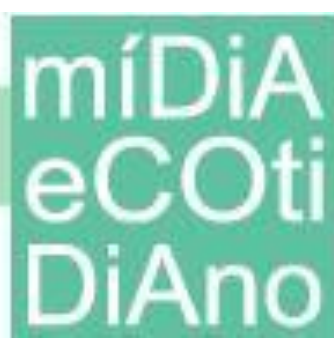

\section{PPGMC}

uff

Figura 4 - Apesar do ângulo, apenas nesta foto o rosto de Juvenita aparece de maneira nítida - o contraste das peles ilustra o efeito Shirley

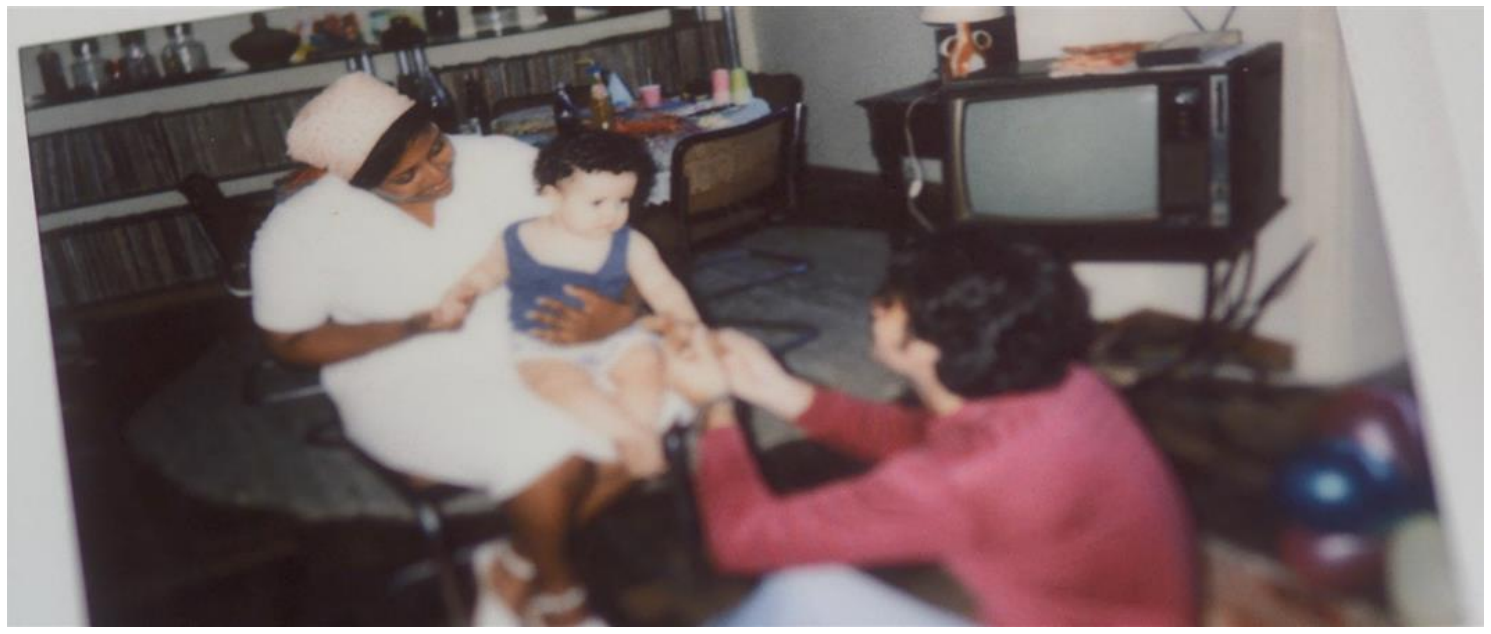

Fonte: Aquarius (MENDONÇA FILHO, 2016).

Figura 5 - Apesar de posar para foto, Juvenita é decepada no enquadramento

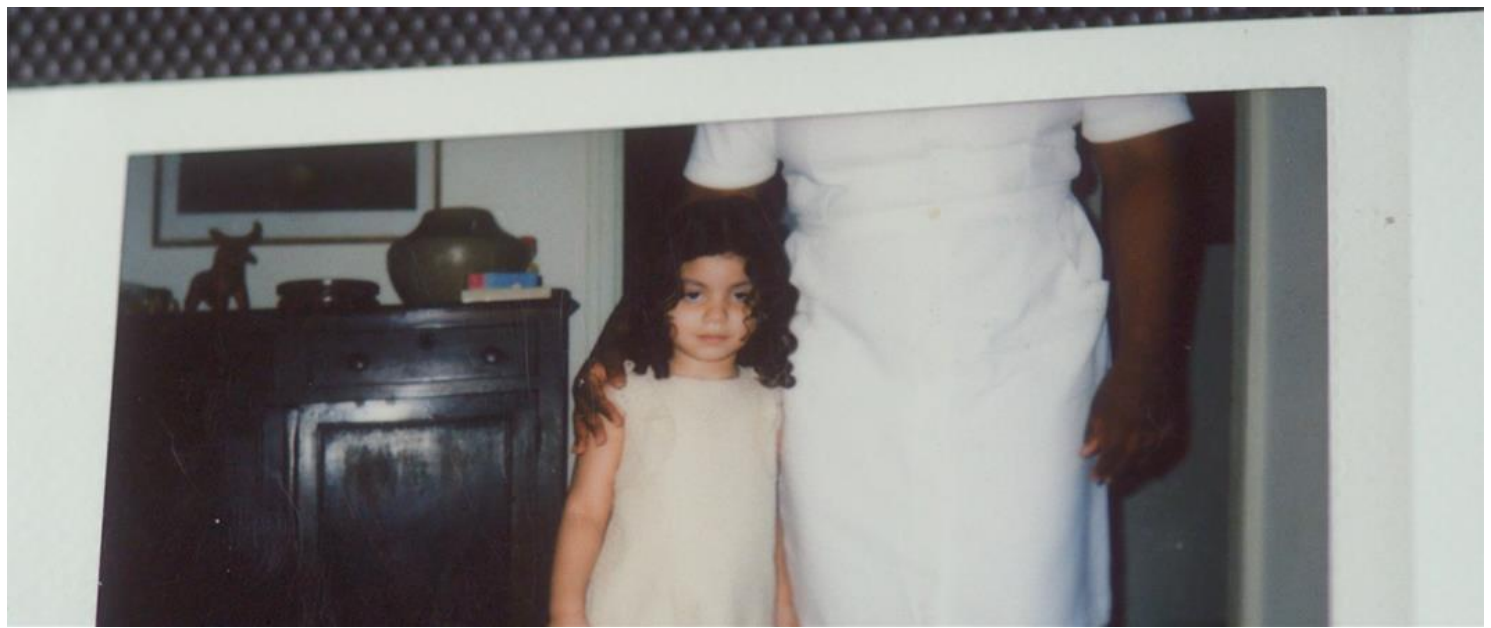

Fonte: Aquarius (MENDONÇA FILHO, 2016).

Ladjane é a primeira palavra emitida por Clara no início do tempo diegético presente do filme, depois do prólogo que se passa em 1980. Enquanto Clara e ninguém da família se lembra do nome de uma empregada que não está mais em convivência, o nome de Ladjane aparece evidenciado na mise-en-scène, o que denota os locais temporais permitidos para a lembrança dos nomes de empregadas domésticas. Por esse entendimento é que, 
Todo dever de memória passa em primeiro lugar pela restituição de nomes próprios. Apagar o nome de uma pessoa de sua memória é negar sua existência; reencontrar o nome de uma vítima é retirá-la do esquecimento, fazê-la renascer e reconhecê-la conferindo-lhe um rosto, uma identidade (CANDAU, 2011, p. 64).

O filme indica, em sua fatura, interesse em representar a realidade brasileira, construir olhares sobre o país. Contudo, há uma complexidade no tratamento da problemática, pois Clara, em um esforço de memória, se lembra do nome de Juvenita na cena do álbum de família. Seria mais didático caso a narrativa avançasse sem a lembrança do nome, porém, ao organizar daquela forma, há uma abertura para entendermos as sutilezas das relações sociais entre patroas e empregadas. Essa composição é trazida também no diálogo entre Clara e a cunhada Fátima, no indicativo da consciência de exploração dos patrões, feito por Fátima, quando Clara fala que Juvenita roubou as joias da família.

Depois das cenas do álbum de família, mais à frente, Clara sonha com Juvenita. O indicativo de sonho aparece por causa do borrado da imagem. A antiga empregada executa a ação pela qual fora lembrada na reunião: rouba as joias da família. Na verdade, no sonho, Juvenita aparece na cozinha e vai em direção ao quarto da patroa. Abre o guarda-roupas, sem titubear, como quem sabe, talvez por conta da convivência cotidiana e arrumação da casa, o local exato onde há uma caixinha de madeira estampada com coqueiros e praia, cujo conteúdo podemos observar um colar de pérolas e anel de brilhantes, que são manuseados por Juvenita, enquanto está sentada na cama. Até então, o enquadramento da imagem não nos informa da presença de Clara, encostada na cabeceira da cama, a observar toda a cena. Esse ponto é revelado enquanto Juvenita, em primeiro plano, observa o brilho do anel: o que se vê é Clara, vestida de branco, com os cabelos soltos, a olhar fixamente para a mulher negra.

Nesse primeiro momento do sonho, há uma associação espacial de significados das personagens. A mulher negra associada à cozinha, tal como na cena do aniversário de Tia Lúcia, no qual três senhoras negras aparecem na cozinha. Ou seja, os espaços ocupados pelas empregadas da casa. $\mathrm{O}$ roteiro do filme ratifica a inflexão em torno das questões de classe ao descrever a cena em termos de "na cozinha calorenta, Clara supervisiona três empregadas suadas, duas delas certamente emprestadas para a festa das 
casas de parentes e amigos, todas de costas, cozinhando, lavando, preparando" (MENDONÇA FILHO, 2020, p. 129).

A mulher negra roubou as joias da família de uma mulher branca, depois fugiu, “escafedeu-se pro Ceará". Juvenita também era a que fazia uma comida muito boa. O que nos remete a um arquétipo amplamente discursivizado na literatura e no cinema: o da mulher negra como cozinheira de "mão cheia". A personagem de Tia Anastácia, criada por Monteiro Lobato, talvez seja aquela de dimensão mais conhecida. Além de cozinheira, Tia Anastácia também era babá, figura associada, na realidade da escravidão e pós-abolição brasileira, à ama de leite, o que nos desloca para a segunda parte do sonho de Clara.

Depois de observar o anel de brilhante, Juvenita olha para Clara. O enquadramento da câmera muda. Se antes o que o espectador observava eram as duas personagens, uma em primeiro plano, de perfil, e a outra em segundo plano, de frente. Agora, vemos apenas Juvenita, de frente, a olhar para a aresta direita da tela, fora da imagem, ou seja, onde estaria posicionada Clara. Juvenita, com um tom de voz preocupado, porém contido, informa: “a senhora tá sangrando". Então, observamos Clara, agora com sangue no peito direito, local onde acontecera o câncer de mama, que a protagonista tivera nos anos 1980. Ela leva a mão em direção ao peito, e, antes que a repouse nele, a cena é cortada para a sala do apartamento de Clara, vazia, apenas com três caixas também vazias, restos de jornais e a cômoda que guarda memórias sexuais de Tia Lúcia.

É Juvenita quem informa a Clara que seu peito está sangrando. Outro indício de que estamos em um sonho é justamente pelo fato de não enxergarmos o peito de Clara vermelho quando Clara observa Juvenita, pois, naquele tempo, é a visão de Clara que constrói a imagem; e, como ela ainda não havia percebido que seu peito estava sangrando, notamos, portanto, um peito sem sangramento.

O dado diegético explica a situação a partir do câncer de mama que Clara lutou em sua juventude. Contudo, outra camada de sentido possível pode vir do observar as significações da mama na história escravocrata brasileira. Há uma troca de papéis: se antes, o peito que sangrava era o negro, e, aqui, o peito visto como metonímia para falar do corpo negro e, em específico, da mulher negra, agora, o peito que sangra é o da mulher 
branca. Juvenita consegue reconhecer esse sangue, pois o peito dela, num sentido metafórico histórico-social, também já sangrou. Ou seja, ela enfrentou dificuldades financeiras e morais. Por essa via, pode-se colocar em diálogo o processo de inserção do negro na sociedade de classes que estava se formando em São Paulo, pós-abolição, a partir da pesquisa do sociólogo Florestan Fernandes no ponto em que explica sobre o papel fundamental da mulher negra. À vista disso,

A mulher negra avulta, nesse período, qualquer que seja a depravação aparente de seus atos ou a miséria material e moral reinante, como a artífice da sobrevivência dos filhos e até dos maridos ou "companheiros". Sem a sua cooperação e suas possibilidades de ganho, fornecidas pelos empregos domésticos, boa parte da 'população de cor' teria sucumbido ou refluído para outras áreas. Heroína muda e paciente, mais não podia fazer senão resguardar os frutos de suas entranhas: manter com vida aqueles a quem dera a vida! Desamparada, incompreendida e detratada, travou quase sozinha a dura batalha pelo direito de ser mãe e pagou mais que os outros, verdadeiramente "com sangue, suor e lágrimas", o preço pela desorganização da "família negra". Nos piores contratempos, ela era o "pão" e o "espírito", consolava, fornecia o calor do carinho e a luz da esperança. Ninguém pode olhar para essa fase do nosso passado sem se enternecer diante da imensa grandeza humana das humildes 'domésticas de cor', agentes a um tempo da propagação e da salvação do seu povo (FERNANDES, 2008, p. 254).

Ao adentrarmos mais nessas teias de sentido, encontramos também a ama de

leite. Tanto no espaço ficcional, como dado de uma realidade,

Personagens recorrentes em pinturas, na literatura de ficção e de memórias, as amas de leite foram representadas como símbolos do carinho e devoção a seus senhores no interior de uma escravidão doméstica, idealmente doce e benevolente. No âmbito das vivências cotidianas, a ocupação de ama de leite impactou de maneira singular as experiências de maternidade e as formas de exploração dos corpos dessas mulheres (TELLES, 2018, p. 99).

As amas de leite eram frequentemente violentadas. Havia a crença de que o leite das mulheres escravizadas tinha mais força, em face do mito de que a raça negra era mais resistente (TELLES, 2018). Muitas das amas tinham seus bebês roubados, mortos ou jogados em orfanatos, logo depois de dada à luz, uma vez que ter dedicação exclusiva para a criança branca era um luxo dos senhores, que negavam toda a violência advinda 


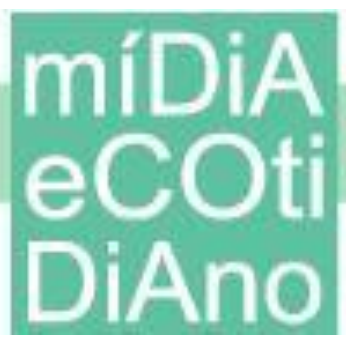

desse ato. Anúncios de jornais da época registravam a fuga das amas das casas dos senhores. A resistência também se dava nos níveis mais trágicos, do sufocamento das crianças amamentadas, pimenta no bico do peito, surtos coléricos, mordidas etc. Um ponto nevrálgico da história brasileira que ainda ecoa, de maneira sutil e silenciosa, nessa cena analisada.

Na montagem, a partir do momento onde é falado do sangue no peito, Juvenita e Clara passam a aparecer em planos separados, como a dizer que as suas experiências partem de lugares muito diferentes. Aqui, como em outros momentos do filme, as experiências de classe e raça aparecem relacionadas, mas não num movimento de a experiência negra se colocar acima, por conta de tudo que ela representa socialmente, da experiência de Clara.

As formas de violência que a mulher negra sofreu e ainda sofre aparecem em Aquarius de uma maneira quase despercebida para quem não é acostumado a ver diretamente o Brasil em seu tilintar racial. Contudo, um desconforto inexplicável permanece, não se sabe exatamente o porquê. Esse desconforto é acentuado pelas sutis camadas de horror movies adicionadas na linguagem de Aquarius.

\section{Considerações finais}

A presença da música Aquarius (Galt MacDermot) estava prevista no roteiro (MENDONÇA FILHO, 2020, p. 128), na primeira cena do início do filme, em 1980, quando Clara pede licença para colocar uma música no toca-fitas do carro recém adquirido do irmão. Portanto, parece não ter sido gratuito o fato de o título do filme ser homônimo da mística e auspiciosa canção da película musical Hair (Milos Forman, 1979). Lançado no mesmo espaço-temporal do período diegético do início do filme, que se deu em 1980, o alinhamento de semelhanças parece costurar um intertexto irônico. A Era de Aquarius onde haverá harmonia, entendimento, libertação verdadeira da mente, onde a paz guiará os planetas e o amor comandará as estrelas parece não ter acontecido no prédio Aquarius. A geração de Clara, herdeira direta da contracultura, em seus movimentos juvenis libertários, se viu frustrada diante da promessa de grandes mudanças anunciadas por esses movimentos. A revolução não aconteceu. 
Embora a promessa da música não tenha se cumprido, o intertexto implícito parece se associar com a sutileza das representações raciais proposta pelo filme. Uma vez que a Era de Aquarius poderia ser a quebra de todas as opressões e, consequentemente, das estereotipias das subjetividades negras no cinema brasileiro, ainda que, atualmente, esteja em estágio tal qual construído pela canção: uma Era do futuro. Mas que Aquarius, de Kleber Mendonça Filho, parece esboçar para um dia acontecer.

\section{Referências}

ARAÚJO, Joel Zito. A negação do Brasil: o negro na telenovela brasileira. São Paulo: Editora Senac, 2000.

BRAGANÇA, Maurício de; SICILIANO, Tatiana Oliveira ; PINTO, Licia Marta da Silva. Interdição e invisibilidade nas representações cinematográficas: a geografia doméstica das empregadas em Que horas ela volta? e Aquarius. Galáxia, São Paulo, n. 42, p. 109-121, 2019.

CAETANO, Lucas Procópio; GOMES, Paula. Medos públicos em lugares privados: o horror nos filmes de Kleber Mendonça Filho. Significação: Revista de Cultura Audiovisual, v. 47, p. 180-201, 2020.

CANDAU, Joel. Memória e identidade. Tradução de Maria Leticia Ferreira. São Paulo: Contexto, 2011.

CANDIDO, Antônio. Literatura e sociedade. 9. ed. Rio de Janeiro: Ouro sobre azul, 2006.

CANDIDO, Antonio et al. A personagem de ficção. São Paulo: Perspectiva, 1992.

FANON, Frantz. Pele negra, máscaras brancas. Bahia: Edufba, 2008.

FERNANDES, Florestan. A integração do negro na sociedade de classes: o legado da raça branca - vol. 1. São Paulo: Globo, 2008.

FREUD, Sigmund. O estranho. In: FREUD, Sigmund. Uma Neurose Infantil e outros trabalhos. Tradução de J. Salomão. Rio de Janeiro: Imago, 1976.

GONZALEZ, Lélia. Racismo e sexismo na cultura brasileira. Ciências Sociais Hoje, São Paulo, n. 2, p. 223-244, 1983.

GREGOLIN, Maria do Rosário. Discurso e mídia: a cultura do espetáculo. São Carlos, SP: Claraluz, 2003.

GUTFREIND, Cristiane Freitas. Cinema. In: CITELLI, Adilson et al. Dicionário de comunicação: escolas, teorias, autores. São Paulo: Contexto, 2014.

HOHLFELDT, Antonio; MARTINO, Luiz C.; FRANÇA, Vera Veiga (org.). Teorias da comunicação: conceitos, escolas e tendências. Petrópolis, RJ, Vozes, 2001. 
LAPERA, Pedro Vinicius Asterito. Do preto-e-branco ao colorido: raça e etnicidade no cinema brasileiro dos anos 1950-70. Tese (Doutorado em Comunicação) - Universidade Federal Fluminense, Instituto de Arte e Comunicação Social, 2012.

MENDONÇA FILHO, Kleber. Três roteiros: O som ao redor; Aquarius; Bacurau. São Paulo: Companhia das Letras, 2020.

MENDONÇA FILHO, Kleber. A cidade e sua arquitetura estão indo contra as pessoas. A Escotilha. 6 set. 2016. Disponível em: http://www.aescotilha.com.br/cinema-tv/central-decinema/kleber-mendonca-a-cidade-e-a-sua-arquitetura-estao-indo-contra-as-pessoas/. Acesso em: 22 nov. 2019.

MUNANGA, Kabengele. As ambiguidades do racismo à brasileira. In: KON, Noemi Moritz; SILVA, Maria Lúcia da; ABUD, Cristiane Curi (Orgs.). O Racismo e o negro no Brasil: questões para a psicanálise. 2. ed. São Paulo: Perspectiva, 2017. v. 1. Cap.1, p. 33-44.

REIS, Carlos; LOPES, Ana Cristina. Dicionário de teoria da narrativa. São Paulo: Ática, 1988.

RIDENTI, Marcelo. Em busca do povo brasileiro: artistas da revolução, do CPC à era da TV. Rio de Janeiro: Record, 2000.

ROTH, Lorna. Questão de pele: os cartões Shirley e os padrões raciais que regem a indústria visual. Tradução de Sergio Tellaroli. Revista de Fotografia Zum. 23 jun. 2016. Disponível em: https://revistazum.com.br/revista-zum-10/questao-de-pele/. Acesso em: 22 nov. 2019.

SHOHAT, Ella; STAM, Robert. Crítica da imagem eurocêntrica. Tradução de Marcos Soares. São Paulo: Cosac Naify, 2006.

SILVERSTONE, Roger. Por que estudar a mídia? São Paulo: Loyola, 2002.

STAM, Robert. Multiculturalismo Tropical: Uma História Comparativa da Raça na Cultura e no Cinema Brasileiros. Tradução Fernando S. Vugman. São Paulo: Editora da Universidade de São Paulo, 2008.

TELLES, Lorena Féres da Silva. Amas de Leite. In: SCHWARCZ, Lilia Moritz; GOMES, Flávio dos Santos (org.). Dicionário da escravidão e liberdade: 50 textos críticos. São Paulo: Companhia das Letras, 2018. p. 99-105. 